\title{
REVIEW: PENERAPAN ASPEK HUMAN ERROR DALAM PENILAIAN KINERJA PADA PERUSAHAAN ALUMINIUM ALLOY WHEEL
}

\author{
Remba Yanuar Efranto dan Anita Galih Saputri \\ Jurusan Teknik Industri Fakultas Teknik Universitas Brawijaya \\ e-mail: remba@ub.ac.id
}

\begin{abstract}
ABSTRAK
Penilaian kinerja pegawai perlu dilakukan untuk mengetahui prestasi yang dapat dicapai setiap pegawai. Dalam memberikan penilaian, kriteria kompetensi penilaian perlu menjadi pertimbangan lebih lanjut. Berdasar hasil observasi yang dilakukan menunjukkan bahwa pelanggaran pekerja yang memicu terjadinya unsafe action di lantai produksi meningkat, sehingga perlu adanya tindak lanjut bagaimana upaya pencegahannya berdasar aspek kinerja. Unsafe action tersebut terkait dengan human error yang menyebabkan kecelakaan kerja. Keadaan inilah yang menjadi dasar bahwa pelanggaran terkait dengan sistem reward dan punishment yang biasa digunakan dalam evaluasi penilaian kinerja karyawan. Pelanggaran standard ataupun prosedur dimaksud dapat memberikan korelasi terhadap hasil penilaian kinerja karyawan. Penerapan aspek human error dalam penilaian kinerja menurunkan potensi pelanggaran pekerja. Hal ini dapat meminimasi terjadinya kecelakaan kerja serta mewujudkan stasiun produksi dengan zero accident.
\end{abstract}

Kata kunci: penilaian kinerja, human error, lantai produksi, unsafe action.

\begin{abstract}
Employee performance assessment needs to be done to determine the achievements that can be achieved by each employee. In providing an assessment, the competency criteria for assessment need to be considered further. Based on the results of observations conducted, it was shown that violations of workers that triggered the occurrence of unsafe action on the production floor increased, so there was a need for follow-up on how prevention efforts were based on aspects of performance. Unsafe action is related to human error that causes workplace accidents. This situation is the basis that violations related to the reward and punishment system are commonly used in evaluating employee performance evaluations. Such violations of standards or procedures can provide a correlation to the results of employee performance appraisal. The application of the human error aspect in the performance appraisal reduces the potential for employee violations. This can minimize the occurrence of work accidents and realize the production station with zero accident.
\end{abstract}

Keywords: performance assessment, human error, production floor, unsafe action.

\section{PENDAHULUAN}

Perwujudan sumber daya manusia yang berkualitas senantiasa diperlukan agar kegiatan dalam perusahaan berjalan dengan baik. Melalui peran aktif dan dominan setiap sumber daya manusia dalam setiap kegiatan organisasi, individu menjadi perencana, pelaku, dan penentu terwujudnya tujuan organisasi [1]. Pengelolaan kinerja yang baik dari sumber daya manusia didukung melalui manajemen sumber daya manusia. Manajemen sumber daya manusia berfungsi sebagai kebijakan dan latihan untuk memenuhi kebutuhan karyawan atau aspek-aspek yang terdapat dalam sumber daya manusia seperti posisi manajemen, pengadaan karyawan atau rekrutmen, penyaringan, pelatihan, kompensasi, dan penilaian prestasi dan kinerja karyawan [2]. Implementasi proses optimalisasi hasil kerja karyawan salah satunya dilakukan melalui penilaian kinerja. Hal ini dilakukan untuk memberikan nilai sehingga karyawan merasa terdorong untuk melaksanakan pekerjaan dan tanggung jawabnya dengan lebih baik.

Kinerja (job performance) adalah hasil kerja secara kualitas dan kuantitas yang dicapai oleh seorang pegawai dalam melaksanakan tugasnya sesuai dengan tanggung jawab yang diberikan padanya [3]. Hasil dari kinerja setiap individu dapat dievaluasi melalui pengukuran kinerja. Selain itu, penilaian kinerja adalah proses evaluasi seberapa baik karyawan melakukan pekerjaan mereka jika dibandingkan dengan seperangkat standar, dan kemudian mengkomunikasikan informasi tersebut pada karyawan [4]. Secara umum melalui pernyataan tersebut, penilaian kinerja dapat didefenisikan bahwa penilaian kinerja merupakan penilaian 
hasil kerja nyata dengan standar kualitas maupun kuantitas yang dihasilkan oleh setiap pegawai. Penilaian kinerja pegawai mutlak harus dilakukan untuk mengetahui prestasi yang dapat dicapai setiap pegawai. Penilaian prestasi penting bagi setiap pegawai dan berguna bagi organisasi untuk mengambil keputusan dan menetapkan tindakan kebijaksanaan selanjutnya.

Penilaian kinerja dapat dilakukan pada setiap bidang pekerjaan baik di industri manufaktur maupun industri jasa. Setiap karyawan diharapkan dapat memberikan kinerja yang baik untuk mendukung perusahaan dalam mencapai tujuan organisasi dalam lingkup yang lebih luas. Hal ini juga dilakukan oleh salah satu perusahaan produsen aluminium alloy wheels. Perusahaan ini selalu berupaya untuk menyediakan roda dan layanan dengan kualitas terbaik melalui biaya rendah dan pengiriman tepat waktu. Karyawan yang bekerja memperkejakan lebih dari 700 pekerja yang terbagi dalam 11 departemen. Dalam pelaksanaan kegiatan produksi, dikarenakan jumlah pekerja dan proses produksinya cukup banyak dan kompleks, ketelitian dan kedisiplinan kerja harus dijalankan sesuai dengan peraturan yang telah ditentukan perusahaan.

Berdasarkan hasil rekap kejadian kecelakaan kerja selama tahun 2014 hingga tahun 2016 telah terjadi cukup banyak kecelakaan kerja yang tentunya berpengaruh terhadap kinerja karyawan. Jumlah kejadian kecelakaan kerja yaitu sebanyak 116 kejadian. Dapat diketahui pula bahwa pada tahun 2014 dengan 41 kejadian mengalami penurunan di tahun 2015 menjadi 34 kejadian, namun pada tahun 2016 mengalami kenaikan menjadi 41 kejadian. Berikut ini merupakan data persentase banyaknya kecelakaan kerja total yang terjadi dari tahun 2014-2016 pada Gambar 1.

Penyebab kejadian kecelakaan kerja secara umum terbagi menjadi unsafe action dan unsafe condition. Pandangan tersebut yang menempatkan unsafe action sebagai penyumbang terbesar kecelakaan kerja, yakni sebanyak 88\% [5]. Tidak sedikit pemimpin yang memberlakukan prosedur kerja yang ketat, sehingga pekerja harus mengikuti aturan tersebut dan tidak boleh melanggarnya. Bila satu kelalaian terjadi, inilah yang dianggap sebagai sebuah unsafe action dan manusia dianggap sebagai akar penyebabnya.

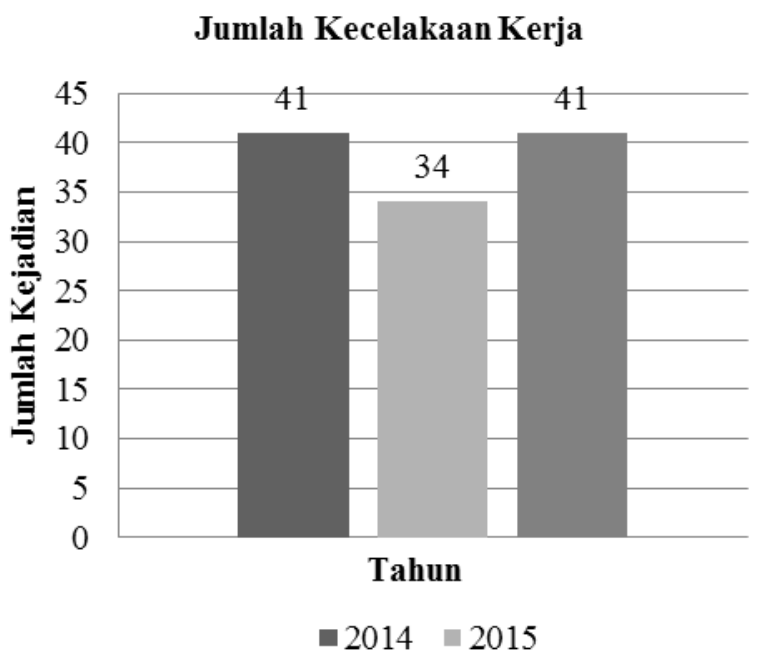

Gambar 1 Data Kecelakaan Kerja Keseluruhan

Berdasarkan data penyebab kejadian kecelakaan kerja dapat diketahui bahwa dari tahun 2014-2016 unsafe action terjadi lebih banyak daripada unsafe condition. Unsafe condition pada perusahaan berupa kondisi lingkungan yang tidak aman seperti jalan licin, debu, mesin tidak layak pakai, dan scrap yang bertebaran, sedangkan unsafe action pada perusahaan berupa tindakan pekerjaan yang tidak aman seperti melanggar peraturan, tidak menggunakan APD, bekerja tidak sesuai dengan prosedur, dan pelangggaran lain yang memang disebabkan oleh human error. Berikut ini merupakan grafik jumlah penyebab kejadian kecelakaan kerja yang disajikan pada Gambar 2. Adanya peristiwa kecelakaan kerja tersebut tentunya dapat menimbulkan dampak negatif bagi perusahaan. Contohnya seperti berkurangnya pekerja, hasil produksi menurun, beban kerja meningkat karena dibebankan kepada pekerja lain, dan biaya yang dibebankan untuk korban kecelakaan kerja. Tindakan tidak aman pada dasarnya diawali dari perilaku setiap pekerja itu sendiri. Berdasarkan data tersebut menunjukkan bahwa unsafe action perlu untuk ditekan karena berasal dari pekerja yang melanggar standar atau ketentuan yang sudah 
dibuat oleh manajemen. Keadaan inilah yang menjadi dasar bahwa pelanggaran terkait dengan sistem reward dan punishment yang biasa digunakan dalam evaluasi penilaian kinerja karyawan. Pelanggaran standard ataupun prosedur dimaksud dapat memberikan korelasi terhadap hasil penilaian.



Gambar 2. Data Jumlah Penyebab Kejadian Kecelakaan Kerja

\section{METODE PENELITIAN}

Pendekatan yang digunakan dalam penelitian ini terdiri dari beberapa tahapan, yaitu;

1. Identifikasi permasalahan dalam tahap pendahuluan. Berikut ini akan dijelaskan mengenai langkah- langkah pemecahan masalah melalui 2 langkah yaitu studi lapangan dan pustaka.

a. Studi Lapangan

Studi lapangan dilakukan dengan cara melakukan pengamatan secara langsung pada perusahaan untuk mengidentifikasi kondisi yang sesungguhnya terjadi di lapangan dan potensi masalah yang dihadapi langsung oleh perusahaan yang dapat diangkat untuk menjadi latar belakang permasalahan. Untuk melakukan studi lapangan, kegiatankegiatan yang dilakukan adalah sebagai berikut.

1) Observasi

Kegiatan observasi dilakukan untuk melakukan pengumpulan data dengan cara mengamati secara langsung permasalahan dan kondisi yang terjadi di perusahaan.

2) Wawancara

Kegiatan wawancara dilakukan untuk menanyakan keadaan-keadaan di perusahaan kepada pihak-pihak yang terlibat pada penelitian yaitu bagian sumber daya manusia dan bagian produksi pada perusahaan dimaksud.

b. Studi Pustaka

Studi pustaka merupakan tahap yang dilakukan untuk mempelajari bagaimana pemecahan masalah dapat dilakukan berdasarkan sumber relevan yang berasal dari penelitian terdahulu, buku, jurnal, teori serta metode yang berkaitan dengan permasalahan.

\section{Pengumpulan Data}

Pada tahap ini akan dijelaskan data-data yang akan dipergunakan untuk mendukung pemecahan masalah. Data yang relevan dengan penelitian akan dikumpulkan untuk diolah dan dibahas lebih lanjut kedepannya. Data yang dibutuhkan terdiri dari 2 data yaitu data primer yang merupakan data yang diperoleh langsung dari hasil penelitian dan data sekunder yang merupakan data yang diperoleh dari sumber yang sudah ada. Berikut ini merupakan data-data yang dibutuhkan pada penelitian:

a. Data Primer, yang terdiri dari:

- Data performance appraisal saat ini

- Data identifikasi human error

b. Data Sekunder

- Pustaka terkait penilaian kinerja

- Job description karyawan

- Data jumlah karyawan

\section{ANALISIS DAN PEMBAHASAN}

Hasil rekap kejadian kecelakaan kerja perusahaan pada seluruh departemen yang ada pada perusahaan, bahwa bagian produksi yaitu Departemen Casting, Painting, dan Machining (CNC), kejadian kecelakaan kerja cukup tinggi dengan total 77 kejadian. Pada Departemen Casting terjadi 30 kecelakaan kerja, departemen Painting terjadi 20 kecelakaan kerja, dan pada departemen Machining dengan 27 kejadian. 
Oleh karena itu, bagian produksi menjadi fokus utama pada penelitan pada penilaian kinerja perusahaan. Grafik persentase kecelakaan kerja berdasarkan departemen yang ada pada perusahaan dari tahun 2014-2016 dapat dilihat pada Gambar 3.

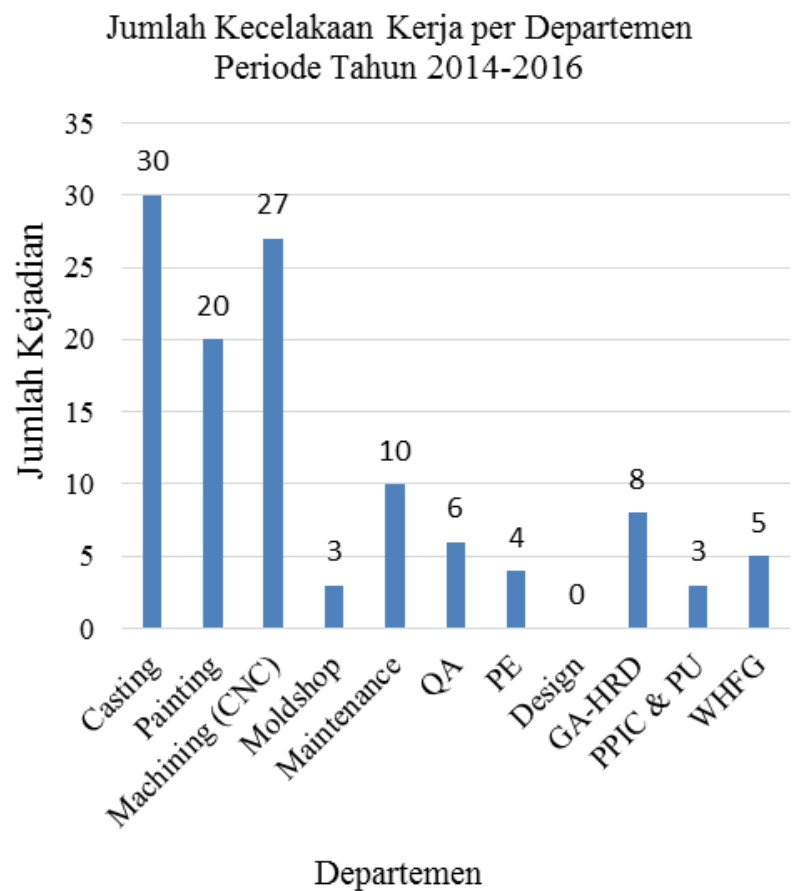

Gambar 3. Data Jumlah Kecelakaan Kerja

Berdasarkan data kejadian kecelakaan kerja pada bagian produksi observasi lebih lanjut dilakukan untuk mendapatkan analisis yang lebih mendalam. Dapat diketahui bahwa Departemen Machining (CNC) mengalami kenaikan kejadian kecelakaan kerja dari tahun 2014 hingga tahun 2016. Walaupun total kejadian terbanyak berada pada Departemen Casting, namun departemen Machining mengalami kenaikan yang cukup signifikan sehingga perlu diketahui penyebab terjadinya kecelakaan kerja tersebut. Diketahui juga bahwa jumlah pekerja di Departemen Machining yaitu 136 pekerja dan sebesar 36,72\% dari pekerja tersebut pernah mengalami kejadian kecelakaan kerja yang umumnya disebabkan oleh human error. Grafik jumlah kecelakaan kerja di bagian produksi dari tahun 2014-2016 dapat dilihat pada Gambar 4.Hasil observasi terebut menunjukkan bahwa kesalahan dalam bekerja menjadi salah satu hal yang perlu mendapatkan perhatian lebih lanjut. Peningkatan jumlah kecelakaan kerja perlu untuk dianalisis lebih lanjut. Apabila karyawan tidak disiplin dalam menaati aturan maka akan terjadi pelanggaran-pelanggaran yang dapat menyebabkan terjadinya kecelakaan kerja. Hal ini menyebabkan faktor kesehatan dan keselamatan kerja sangat penting diterapkan karena kesehatan dan keselamatan kerja adalah suatu pemikiran dan upaya untuk menjamin keutuhan dan kesempurnaan baik jasmaniah maupun rohaniah tenaga kerja pada khususnya, dan manusia pada umumnya, hasil karya dan budaya untuk menuju masyarakat adil dan makmur [3].

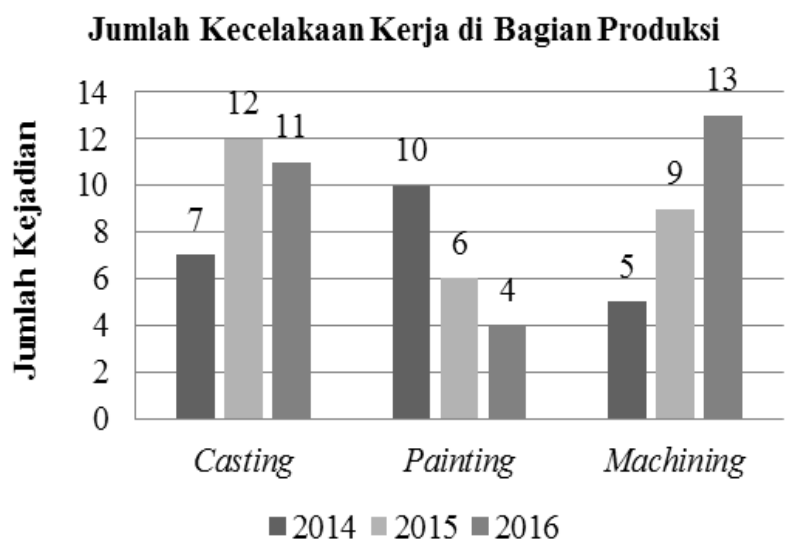

Gambar 4. Grafik Kecelakaan Kerja di Bagian Produksi

Kecelakaan kerja adalah kecelakaan dan atau penyakit yang menimpa tenaga kerja karena hubungan kerja di tempat kerja [6]. Secara umum, faktor penyebab terjadinya kecelakaan kerja dapat dibedakan menjadi faktor pekerja itu sendiri (human error), faktor metoda konstruksi, peralatan, dan manajemen. Di sisi lain penting bagi tiap pekerja, terutama managernya, untuk menjadi lebih mawas diri akan potensi manusia berbuat salah [7]. Pekerjaan, tempat kerja dan faktor organisasasi membentuk kemungkinan (likelihood) dan konsekuensi (consequences).

Disisi lain, penilaian kinerja berarti melakukan evaluasi kinerja karyawan pada saat ini dan/ atau di masa lalu yang relatif terhadap standar kinerjanya. Penilaian kinerja juga selalu mengasumsikan bahwa karyawan memahami apa standar kinerja mereka, dan penilai juga 
memberikan karyawan umpan balik, pengembangan, dan insentif yang diperlukan untuk membantu orang yang bersangkutan menghilangkan kinerja yang kurang baik atau melanjutkan kinerja yang sudah baik [2]. Dapat disimpulkan bahwa penilaian prestasi kerja adalah suatu proses yang digunakan untuk menentukan apakah seorang karyawan melakukan pekerjaannya sesuai dengan tugas dan tanggung jawabnya salah satunya tidak melakukan tindakan yang berkaitan dengan human error.

Human error adalah kegagalan untuk melakukan tugas atau tindakan pelanggaran yang konsekuensinya menyebabkan kerusakan serius, kerusakan properti, dan insiden lainnya yang dapat mempengaruhi/menyebabkan penurunan kinerja karyawan [8]. Hal ini menunjukkan bahwa kesehatan dan keselamatan kerja karyawan merupakan hal yang sangat penting untuk dipertimbangkan sehubungan dengan pencapaian tujuan organisasi dan peningkatan kinerja karyawan. Human error yang minim akan mengurangi kecelakaan kerja sehingga dapat meningkatkan kedisiplinan dan prestasi pekerja dalam menjalankan pekerjaannya. Selain itu untuk menciptakan lingkungan kerja yang mendekati zero accident yang tentunya menjadi salah satu tujuan yang diharapkan perusahaan. Untuk itu akan dilakukan penelitian pada proses penilaian kinerja pada perusahaan berdasarkan masalah kecelakaan kerja tersebut.

Human error didefinisikan sebagai suatu keputusan atau tindakan untuk mengurangi atau berpotensi mengurangi efektifitas, keamanan, atau performansi suatu sistem. Menurut Perilaku berbahaya adalah kegagalan (human failure) dalam mengikuti persyaratan dan prosedur-prosedur kerja yang benar sehingga menyebabkan terjadinya kecelakaan kerja [9]. Perilaku berbahaya adalah kesalahan-kesalahan (error) dan pelanggaran-pelanggaran (violation) dalam bekerja yang dapat menyebabkan kecelakaan kerja. Memahami bagaimana dan mengapa tindakan tidak aman terjadi adalah langkah awal penting dalam mengelola kesalahan dengan efektif, maka faktor human error penting untuk diperhatikan untuk mencegah terjadinya kecelakaan kerja. Faktor human error dapat menjadi sebuah pertimbangan dalam menilai kompetensi setiap individu dalam melaksanakan tugasnya.

Berdasar penelitian sebelumnya, penelitian telah dikembangkan untuk mengidentifikasi kompetensi keselamatan kerja. Kumpulan indikator berbasis perilaku dari tiap kompetensi dan pengukuran perilaku dilakukan untuk mencegah terjadinya human error di salah satu pembangkit tenaga nuklir di Korea Selatan. Penilaian dilakukan dengan menggunakan metode Behaviorally Anchored Rating Scale (BARS) dan Behavior Observation Scale (BOS). Kompetensi keselamatan kerja dan perilaku individu diturunkan dari lima langkah kompetensi terdahulu yang berasal dari literatur, hasil analisis, hasil interview dan penerapan indikator yang telah divalidasi [10].

Oleh karena itu perlu adanya perbaikan penilaian kinerja yang memasukan faktor human error yang telah dilakukan identifikasi sebagai pencegahan terjadinya peristiwa kecelakaan kerja maupun pelanggaran agar karyawan selalu disiplin dan termotivasi, serta patuh terhadap aturan yang ada. Penerapan ini diharapkan dapat memberikan pengaruh yang signifikan khususnya dalam pencegahan terjadinya human error yang dapat mengurangi performansi dari setiap karyawan.

Penilaian kinerja karyawan dilakukan dengan mempertimbangkan aspek human error. Aspek human error dapat diidentifikasi melalui Human Error Indentification (HEI). Human Error Identification (HEI) adalah klasifikasi langkah tugas yang bertujuan untuk memeriksa kesalahan tindakan melalui klasifikasi tingkat rendah kesalahan dimana penjelasan terjadinya pada setiap error yang disajikan [11]. Berikut ini merupakan klasifikasi tindakan error:

1. Action Error yang berkaitan dengan tindakan yang dilakukan individu dalam melakukan aktivitasnya atau menyelesaikan tugasnya.

2. Retrieval Error berkaitan dengan pengembalian sistem menjadi keadaan semula akibat dari aktivitas yang salah.

3. Checking Error berkaitan dengan kesalahan yang dilakukan individu yaitu tidak melakukan pengecekan dengan tepat pada 
suatu aktivitas tertentu.

4. Communication Error berkaitan dengan kesalahan dalam proses berkomunikasi dengan bagian atau individu lainnya seperti kesalahan dalam menyampaikan informasi.

5. Selection Error berkaitan dengan kesalahan operator dalam memilih salah pilihan atau lupa untuk memilih langkah dalam proses untuk mengendalikan sistem.

Melalui klasifikasi tersebut aspek human error ditambahkan sebagai salah satu kompetensi yang dipertimbangkan dalam penilaian. Harapannya, dengan tidak adanya kesalahan dalam bekerja dapat meningkatkan kinerja karyawan, dan apabila kesalahan dilakukan maka kinerja yang bersangkutan konsekuensinya akan menurun. Penambahan kompeteni ini diharapkan mampu menghasilkan penilaian yang objektif serta memperoleh feedback yang baik bagi karyawan. Tercapainya lingkungan kerja yang zero accident semoga dapat terwujud sehingga dapat mendukung pencapaian visi misi dan tujuan perusahaan.

\section{KESIMPULAN}

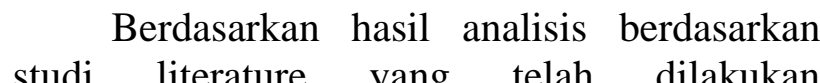
menunjukkan bahwa penambahan aspek human error sebagai salah satu kompetensi dalam penilaian kinerja dapat dilakukan. Penentuan kompetensi tambahan tersebut diharapkan dapat memberikan suatu umpan balik bagi setiap karyawan dalam setiap aktivitasnya. Diharapkan melalui penambahan kompetensi berdasar aspek human error dapat mendukung perwujudan zero accident, khususnya di stasiun produksi.

\section{DAFTAR PUSTAKA}

[1] Hasibuan, Malayu. (2012). Manajemen Sumber Daya Manusia. Jakarta: PT Bumi Aksara.
[2] Dessler, Gary. 2010. Manajemen Sumber Daya Manusia (edisi kesepuluh). Jakarta Barat: PT Indeks.

[3] Mangkunegara, Anwar. (2007). Manajemen Sumber Daya Manusia. Perusahaan. Bandung: Remaja Rosdakarya.

[4] Mathis, R.L. dan J.H. Jackson. (2006). Human Resource Management: Manajemen Sumber Daya Manusia. Terjemahan Dian Angelia. Jakarta: Salemba Empat.

[5] Heinrich, H. W. \& Petersen, D. \& Roos, N. (2012). Industrial Accident Prevention. New York: McGraw-Hill.

[6] Ervianto, I.W. (2005). Manajemen Proyek Konstruksi Edisi Revisi. Yogyakarta. Andi.

[7] Reason, J. (1990). Human Error. Cambridge University Press.

[8] Dhillon, B. S. (2002). Engineering Maintenance "A Modern Approach". New York: CRC Process LLC.

[9] Winarsunu, Tulus. (2008). Psikologi Keselamatan Kerja. Yogyakarta: UMM Press.

[10] Moon, Kwangsu et al (2016). Development of Safety Competences, Behavioral Indicators and Measuring Methods for Preventing Human-Error. Journal of the Korean Society of Safety. Vol. 31, No. 1, pp. 132-138. Chung-Ang University.

[11] Stanton, Neville et al. (2005). Handbook of Human Factors and Ergonomics Methods. London: CRC Press. 